\title{
PLANNING FOR CHANGE: ADDRESSING ENVIRONMENTAL MIGRATION AS A PLANNING ISSUE IN THE GREATER TORONTO AREA
}

\author{
by \\ Erin James Windross \\ BA, Urban Studies, University of Calgary, 2014 \\ A Major Research Paper \\ presented to Ryerson University \\ in partial fulfillment of the requirements for the degree of \\ Master of Planning \\ in \\ Urban Development
}

Toronto, Ontario, Canada, 2016

(C) Erin James Windross 2016 
I hereby declare that I am the sole author of this MRP. This is a true copy of the MRP, including any required final revisions.

I authorize Ryerson University to lend this MRP to other institutions or individuals for the purpose of scholarly research

I further authorize Ryerson University to reproduce this MRP by photocopying or by other means, in total or in part, at the request of other institutions or individuals for the purpose of scholarly research.

I understand that my MRP may be made electronically available to the public. 


\title{
PLANNING FOR CHANGE: ADDRESSING ENVIRONMENTAL MIGRATION AS A PLANNING ISSUE IN THE GREATER TORONTO AREA
}

(C) Erin James Windross, 2016

\author{
Master of Planning \\ in \\ Urban Development \\ Ryerson University
}

\begin{abstract}
This paper aims to provide a background on a future climate change induced refugee crisis and the potential planning responses that may be warranted in the Greater Toronto Area (GTA). A review of academic literature and policy documents indicate that such a climate change refugee crisis is within the realm of possibility. As a result, under current federal refugee policy, Canada will likely see an increase in episodes of refugee resettlement. For municipalities within the GTA, one of the most ethnically diverse regions in North America, it is recommended that planners and planning regimes incorporate multicultural planning practices to address and anticipate the needs of these future newcomers.
\end{abstract}

Key words: Environmental migration; climate change; refugees; cities; planning; Toronto 


\section{ACKNOWLEDGEMENTS}

I would like to acknowledge my MRP supervisor, Zhixi Zhuang, as well as my second reader, Christopher Gore, for the constructive and insightful feedback they provided for this project. 


\section{Table of Contents}

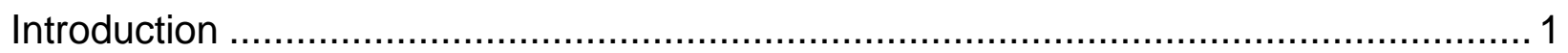

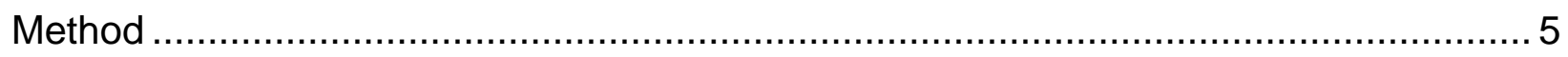

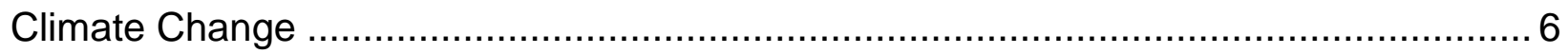

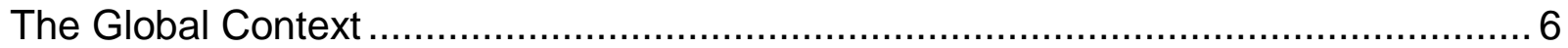

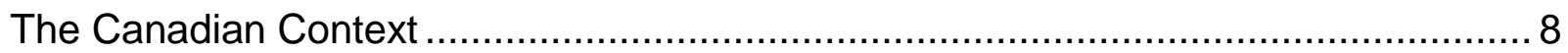

Local and Regional Effects ....................................................................... 9

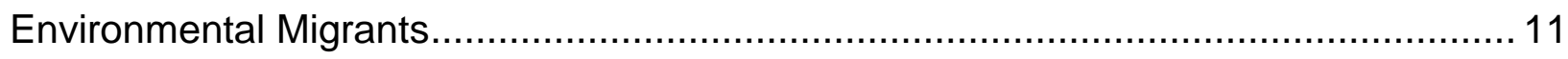

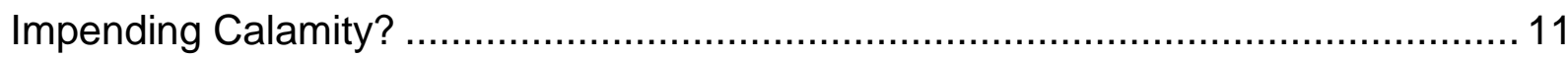

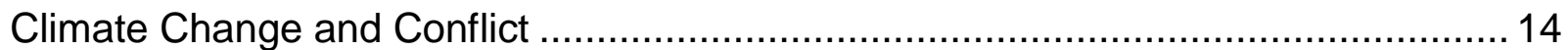

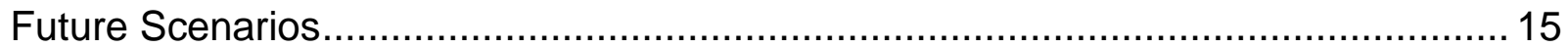

Canadian Refugee Policy: Past and Futures...................................................... 18

A Brief History of Refugee Asylum in Canada....................................................... 18

Current Canadian Refugee Policy.......................................................................... 20

Environmental Migrants and Canada's Refugee Regime ..................................... 22

Refugees and Newcomers in Metropolitan Toronto …........................................... 25

The Context of Ethno-Cultural Diversity in Metropolitan Toronto .............................. 25

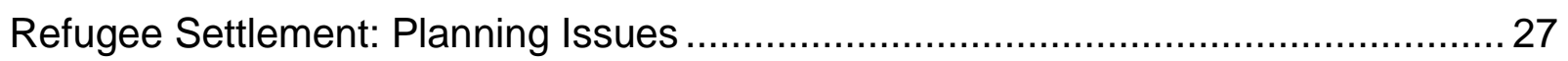

Multicultural Planning: A Direction for the Future? .................................................. 30

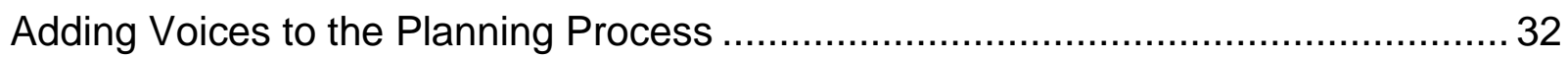

Addressing and Anticipating Cultural Differences .................................................. 32

Emphasizing Diverse Services for Communities................................................. 34

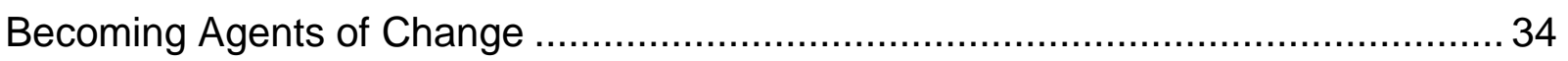

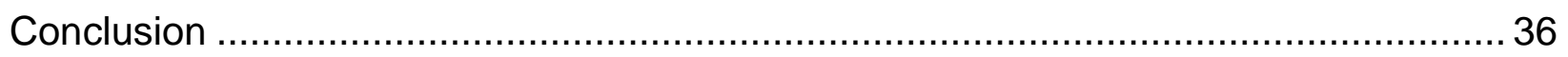

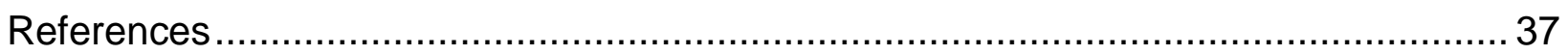




\section{Introduction}

For decades, metropolitan Toronto has been one of the primary receiving and settlement areas for refugees arriving in Canada. Yet the uncertain and unpredictable nature of federal refugee policy in Canada leaves municipalities in the region unable to reliably plan for or adapt strategies for resettlement should there be large or unexpected influxes of these newcomers (Reynolds \& Goffin, 2016). This may have serious land-use and community planning implications should global refugee numbers grow. Unfortunately, that may soon be the case if the predicted effects of climate change are borne out over the next century. For planners in the Greater Toronto Area (GTA) it may be prudent to start investigating how land-use policy and planning could potentially overcome the challenges associated with such future refugee intake episodes.

Under the United Nations Convention Relating to the Status of Refugees, the term 'refugee' is defined as a person who, "owing to a well-founded fear of being persecuted for reasons of race, religion, nationality, membership of a particular social group or political opinion, is outside the country of his nationality, and is unable to, or owing to such fear, is unwilling to avail himself of the protection of that country" (UN General Assembly, 1951). Notably, this definition does not list the environment as a reason a person may become a refugee. However, the International Organization for Migration has included environmental changes as a factor in its formal definition of an environmental migrant:

“[...] persons or groups of persons who, for compelling reasons of sudden or progressive changes in the environment that adversely affect their lives or living conditions, are obliged to leave their habitual homes, or choose to do so, either temporarily or permanently, and who move either within their country or abroad.” (IOM, 2007: p. 1-2) 
Yet this definition is not formally recognized under any international framework or convention, including the United Nations Convention Relating to the Status of Refugees. Environmental migration is also not a recognized category for seeking asylum in Canada. In fact, there is a profound absence of international and national policies that define or recognize individuals displaced by sudden or gradual environmental degradation as refugees. Although the final approved text of the 2015 United Nations Climate Summit (COP21) refers to migration patterns changing due to climate change, it does not classify those displaced populations as refugees (Chan, 2015).

The lack of international recognition of those displaced by climate change or environmental degradation as refugees has not dissuaded their categorization as such by activists, academics and policymakers (Bettini, 2013). For some, the matter is an urgent one, with the prospect of millions of displaced persons looming on the horizon. The most widely cited estimate of displacement as the result of climate change comes from Myers (2002), who predicts a future where hundreds of millions are forced to abandon their settlements by mid-century due to rising sea levels and agricultural failures. However, considerable debate has occurred over these estimates, with serious questions raised about their methodologies and academic rigour (Gemenne, 2011; Bettini, 2013; Nicholson, 2014). Attempts have been made to develop more rigorous methods of measurement, yet a consensus among scholars has failed to emerge due to the complexity of migration decisions (Reuveny 2007; Buhaug 2015). Although it appears undeniable that humans react to changes in their environment, this apparent disconnect between "commonsense" reasoning and empirical evidence remains unresolved.

Despite the lack of official status for those who are displaced by climate change or environmental degradation it may not be necessary to create a new category in order to anticipate 
their status as refugees. For example, there is mounting evidence that the current Syrian civil war was aggravated and catalyzed by an unprecedented drought that occurred between $2006 \& 2010$, which itself can be linked to changes in climatic conditions (Gleick, 2014). Indeed, current security minded discourse describes climate change as a threat-multiplier - that is, while the phenomenon is not a direct source of conflict (if it were, neighboring Jordan would be in similar turmoil), it will certainly exacerbate volatile situations in vulnerable regions (Brown \& McLeman, 2009). Assuming refugee classification does not change federally or through the United Nations Human Rights Council (UNHCR) and assuming the impacts of climate change occur as predicted, refugees will likely increase in number simply by virtue of the fact that more conflicts will arise as climate change aggravates existing tensions through environmental degradation and resource depletion. In other words, regardless of classification, many individuals will eventually become climate refugees by another name.

In the absence of international or national policies to address the issue of population displacement as a result of climate change, this paper argues that municipalities in Canada, and specifically those in metropolitan Toronto, should go further to incorporate multiculturalism into land-use and community planning in anticipation of a likely increase in both the amount and frequency of refugee flows. I will note that my assumption of an increase in refugee flows into Canada as a result of climate change is made without assuming a change in federal refugee policy. That said, existing research on environmental migrants and Canada's refugee policy indicates that containment and exclusion will likely become the normative model at higher governance levels for dealing with a future crisis (Murray, 2010). Future governments may adjust policies to become more restrictive should Canada face pressure to resettle large numbers of refugees. Indeed, recent 
changes to Canada's refugee policy indicate that this is not an unlikely scenario depending on the party in power and the crisis, real or perceived, that arises (Hari, 2014).

This study begins with an outline of my method. An overview of climate change concerns will follow, as well the predicted effects in Canada, Ontario and the GTA. I will then review current assessments of the relationship between climate change, environmental degradation and human migration patterns in order to analyze the current state of research on climate-induced migration. A brief account of the debate surrounding the classification of environmental migrants will be included. Following this, I will summarize Canadian refugee policy, along with an assessment of the factors that guide its implementation and evolution. A discussion of refugee experience and settlement in the GTA will follow. Finally, I will identify potential municipal level planning responses to future refugee resettlement through the implementation of multicultural planning strategies. 


\section{Method}

My paper aims to provide an understanding of the emerging issue of climate change and environmental migration and how planners in the GTA might proactively respond to future refugee flows. In order to evaluate what this response might look like or whether it is even warranted, this paper reviews current literature on climate change and its effect on human migration. Further to this, it is also informed by historic and current refugee policy in Canada, as well as the settlement experiences and challenges for refugees and newcomers in the GTA. In turn, recommendations for current planning practice are suggested through the lens of multicultural planning.

My observations and analysis are derived from secondary data, including: academic journal articles; books; statistics; government policy, papers and reports; newspaper articles; scientific websites; NGO reports; consultant reports; and, municipal land-use documents. Ultimately, I aim to give interested planners a primer on this topic, how it relates to planning in metropolitan Toronto, and provide suggestions for potential planning responses. 


\section{Climate Change}

"It was, I would say, absurdly warm across the entire Arctic Ocean." That was how Mark Serrez, director of the National Snow and Ice Data Center, described the Arctic temperature anomaly of January, 2016 to the Washington Post (Mooney, 2016). Air temperatures across the Arctic Ocean were over $6^{\circ} \mathrm{C}$ above average (National Snow and Ice Data Center, 2016), causing dramatic loss of sea ice and stunning researchers. This temperature anomaly, though an outlier due to a strong El Nino in the Pacific, continues an Arctic warming trend that has been ongoing for the past several decades. Climate models predict that the Arctic could see ice free summers by the middle of the century, if not earlier (Wang \& Overland, 2012). The impacts of an ice-free Arctic will have dramatic and unprecedented effects for Arctic eco-systems, coastlines, wildlife and human communities (Arctic Climate Impact Assessment [ACIA], 2005). As the $21^{\text {st }}$ century continues, it is likely that environmental conditions in the Arctic and across the planet will continue to deteriorate as a result of global warming.

\section{The Global Context}

It is now virtually indisputable that human based carbon emissions are warming the Earth's atmosphere. The Fifth Assessment Report of the Intergovernmental Panel on Climate Change (IPCC) identifies human production activities as the primary source for greenhouse gas (GHG) emissions over the past 150 years, leading to a commensurate rise in $\mathrm{CO} 2$ concentrations in the atmosphere from 290 to $440 \mathrm{ppm}$. These gases, CO2 in particular, block solar radiation from leaving the atmosphere and create a warming effect: hence their 'greenhouse' namesake, as the process is notionally similar. On average, the planet is expected to warm by $2{ }^{\circ} \mathrm{C}-6^{\circ} \mathrm{C}$ over the 
next century depending on how quickly GHG emissions are cut. ${ }^{1}$ This does not mean that temperatures will rise everywhere: some areas of the earth will experience warming, some will experience cooling, and global climates overall will become more variable. This is, essentially, climate change.

According to the IPCC (2015), unless greenhouse gas emissions from human activities are stabilized and average global temperatures kept from crossing a rise of $2{ }^{\circ} \mathrm{C}$ Celsius, climate change will bring deeply felt and long-lasting negative effects. These include: increased storm frequency and intensity, a decline in areas of agricultural production, inundation of coastal communities, ocean acidification, ecosystem degradation and loss of biodiversity, and shrinking availability of fresh water due to drought or salinization by rising oceans.

The commensurate economic and social costs of climate change will vary depending on the rise in temperatures. The widely cited Stern Review (2007) of the economic impact of climate change envisions the effects to cost $2-5 \%$ of global GDP per year, compounded further over time if there is a delay in curbing emissions and limiting temperature rise. Of particular note with the Stern Review is its assertion that the societies which will endure the most hardship from climate change will be some of the poorest and least capable of adapting. For example, agricultural production in developing countries are often susceptible to even slight changes in climatic conditions due to lack of institutional capacity to deal with a decline in yields. In other words, a drier than usual growing season is likely to have much different outcomes in Belgium compared to Mali. This also speaks to the fundamental inequity and unfairness of climate change. Countries

\footnotetext{
${ }^{1}$ The 2015 Paris summit ended in December, 2015 with commitments to keep global temperature rise below a maximum of $2{ }^{\circ} \mathrm{C}$ above pre-industrial levels, with a temperature rise of no greater than $1.5{ }^{\circ} \mathrm{C}$ above pre-industrial levels as a target (United Nations, 2015). Global surface temperatures in February, 2016 were $1.35^{\circ} \mathrm{C}$ above the long-term average for that month, breaking the previous record set in January, 2016 (Carrington \& Slezak, 2016).
} 
with the highest per-capita GHG emissions are also the ones that will be the least affected, while nations with some of the lowest per-capita GHG emissions are the ones most likely to suffer the brunt of the effects (Tol et al., 2004).

\section{The Canadian Context}

In a warming world, Canada will likely be among the least affected, relatively speaking. The country's northerly position, vast landmass, sparse population and enormous fresh water reserves $^{2}$ renders it one of the few nations that should, in theory, manage or withstand the changes of climate change. Of course, this is to not say Canada will be immune to the effects. Summers will be hotter, winters will have less snow, and the health and resilience of Canadian ecosystems will be negatively impacted ${ }^{3}$ (Chen, 2011). In the north, arctic tundra may be reduced by half and permafrost could disappear completely (Rencz, 2012). Increased evapotranspiration and earlier spring melts from melting glaciers will cause water shortages that will negate any increase in the growing season for the Canadian prairies (Diaz et al., 2010). Forest health and biodiversity across the country will continue to decline due to increased incidence of drought, pests, disease and fires (Williamson, 2009). Yet despite such ominous outlooks, Canada will likely fare much better than other nations. For instance, it is now predicted that under a business as usual scenario of carbon emissions, areas of the Arabian Gulf will experience temperatures beyond the limit for human survival by 2100 (Pal \& Eltahir, 2016). The privileged position Canada will enjoy going forward into the future has not gone unnoticed: some scholars have posited that northern areas of the

\footnotetext{
${ }^{2}$ Although Canada has close to $20 \%$ of all fresh water on earth, only around $6.5 \%$ of this is part of the hydrological cycle, with the rest stored in permafrost and ice (Sandford, 2012). Nevertheless, for a country of 30 million people (about half-a-percent of the global population) this is still an enormous amount.

${ }^{3}$ An example of the interplay of all these factors is evidenced in the salmon runs of British Columbia as described by Cozier et al. (2008). Earlier and warmer spring temperatures affect when salmon fry leave spawning nurseries, as water temperature is closely linked to their emergence. However, food availability may not advance at the same rate as temperature increase. This can cause mortality and lead to deleterious effects farther up the food chain.
} 
country will eventually become one of the few places humanity will be able to refuge should climate change spiral out of control (Lovelock, 2009; Dyer, 2008; Giles, 2013). However, the imprecise nature of predicting the severity of climate change warrants some skepticism of such viewpoints.

\section{Local and Regional Effects}

Ontario and the Greater Toronto Area will also experience adverse effects from climate change, although not nearly to the extent of more vulnerable regions. In 2007, the Ontario Ministry of Natural Resources produced a report on the expected impacts of climate change in the province. Under a scenario of increasing carbon emissions over the next century, Southern Ontario is expected to experience hotter summers and warmer winters with 10 to 20 per cent less precipitation (Colombo et al., 2007). More recent research points to temperature ranges above those predicted in the 2007 report with added precipitation variability due to an increase in the intensity of rainfall events (Wang et al., 2015; Wang et al., 2015a). For the GTA, less snow and more rain is predicted for winter, while more destructive storms and more extreme heat events are predicted for summer (Toronto Environment Office, 2008; City of Toronto, 2011). Additional climate change impacts range from lower water levels in Lake Ontario to more incidence of invasive species (Ligeti et al., 2006).

However, even with these predictions, the GTA will occupy an enviable position in the world. The inland location of the region, its moderate climate and its ready access to fresh water will likely ensure relative stability compared to other jurisdictions. For example, New York City is contending with sea levels that could rise up to six feet by the end of the $21^{\text {st }}$ century and cost billions to mitigate (New York City Panel on Climate Change, 2015). Other cities in developed nations, many of them coastal, are contending with similar problems and are grappling with the 
enormous investments necessary to prepare for the effects of climate change. This is to say nothing of vulnerable population centres in developing countries that will face the impacts of climate change without the means to adapt. Intuitively, it would then seem to make sense that the residents of such places would attempt to seek refuge in areas of the world that will not be as affected by climate change; including Canada and the global north. Yet over the past decade, despite the incontrovertible evidence of the onset of climate change, this type of migration does not appear to have materialized in any explicit or quantifiable form (Pearce, 2011; Gemmene, 2011). Moreover, the vast amount of migration caused by climate change is predicted to be internal rather than international (McLeman, 2014). Are these numbers nothing more than fear mongering? The next section of this paper intends to critically examine the notion of climate change and migration in order to understand what, if any, international migration crisis the world may face as the result of global warming. 


\section{Environmental Migrants}

Over the past decade, considerable attention has been paid to the potential for climate change to displace populations in vulnerable locations. It has been popularly assumed that an enormous tide of human migration will occur as low-lying coastal cities are inundated, agricultural areas parched, and storms increase in frequency and intensity. The people displaced -- notionally described as climate refugees, environmental migrants, or some variation of these terms - will overwhelm transit states with their numbers and, eventually, end up on the doorstep of western nations. This apocalyptic theme has emerged as part of the popular discourse on climate change outside and within academia (Bettini, 2013). For example, the drought experienced in Syria from 2006-2009 has been identified by some as a causal factor in that nation's protracted civil war and refugee crisis (Gleck, 2014). Yet despite relatively straight-forward assertions that changes in climate will have commensurate changes in migration patterns, the issue remains "chaotic" (Nicholson, 2014, p. 151). Recent studies have attempted to address the lack of coherency in this field with varying degrees of success. Environmental migration decisions, as it turns out, are the result of a complex array of factors and cannot be reduced to single cause (See McLeman, 2014 for an excellent and extensive overview). However, despite the lack of empirical evidence, it seems to be a common thought among organizations such as the World Bank that climate change will act as a threat-multiplier for existing and future conflicts (Raleigh, 2008).

\section{Impending Calamity?}

In order to gauge how climate change will affect migration patterns, it is important to critically examine alarming claims of displacement. The best known and most widely referenced prediction of mass migration resulting from climate change comes from Myers (2002), who projected that by 2050 the number of people displaced would exceed 200 million. This figure has 
become popularly cited in advocacy campaigns, academic literature, grey papers and government reports, including the Stern Review on the Economics of Climate Change (2007). Other predictions have been more specific (Christian Aid, 2007) or more general (Reuveny, 2007). Yet although these figures are useful for political traction and advocacy, their methodologies and academic rigour leave much to be desired (Gemenne, 2011; Bettini, 2013; Nicholson, 2014). In some cases, backlash has occurred when numbers have failed to materialize, as was the case when international agencies predicted 50 million displaced persons from climate change by the year 2010 (Pearce, 2011). Deriving reliable estimates of how many people will be displaced by climate change is a considerable challenge and has led to a significant gap between empirical measurement and popular perception.

As with any new line of inquiry, attempts have been made to develop frameworks of understanding in response to a vacuum of information. Analytical as well as empirical models have both been developed to explore how migration is influenced by environmental conditions. These include decision matrixes and frameworks (Warner et al., 2010; Black et al., 2011; Perch-Nielsen et al., 2008), case studies (Oppenheimer, 2012) and generalized models of migration flows (Marchiori \& Schumacher, 2011). Yet no coherent framework or methodology has yet to emerge. Obokata et al. (2014) notes that our understanding of the relationship between climate change and migration is comparable to the early days of climate-science, with similar issues of scope, scale, methodology and data availability. Currently, the most reliable estimate of displacement caused by environmental conditions comes from the Internal Displacement Monitoring Centre (IDMC), which estimates the number of those displaced by natural disasters at 26.4 million people per year on average since 2008 (Yonetani, 2011). However, these figures do not include individuals who may be displaced by slow acting processes such as mean-sea level rise or desertification (Bettini, 
2013). McLeman (2014) also points out that there are issues of classification when it comes to quantifying displacement. For example, an elderly retired couple permanently relocating to Victoria, BC from Red Deer, Alberta in order to experience milder winters is an example of environmental migration; yet they would certainly not be classified as refugees (ibid.). Capturing the empirical evidence that describes a relationship between climate change and migration is ongoing and remains a topic of considerable debate.

Under this uncertainty, it is worth pointing out that only real consensus between researchers involved in the study of environmental conditions and human migration is that environmental degradation is just one of a suite of factors that play into whether a household decides relocate (see Warner et al., 2009 for a summary). However, as several scholars have noted, this relatively straightforward statement comes dangerously close to being tautologically useless (Nicholson, 2014; Hartmann 2010; Bettini \& Andersson 2014). Certainly it is undeniable that human beings influence and are influenced by the climatic conditions we experience. ${ }^{4}$ Our species has managed to permanently inhabit virtually all land-based terrestrial ecosystems, save for those with exceptionally harsh climatic conditions, such as polar regions and deserts. Yet the "commonsense" notion that climate change will influence a person's decision to permanently relocate is still without an empirical basis. ${ }^{5}$ Since there are apparent limitations in the methodologies of these linkages, it may be useful to look to at similar fields for quantitative guidance.

\footnotetext{
4 See Diamond (2005) for a popular viewpoint on this subject.

${ }^{5}$ Although it may not be a primary reason for relocating, ongoing qualitative research does suggest that environmental conditions are a second or third order consideration for some recent immigrants to Canada (Veronis \& McLeman, 2014).
} 


\section{Climate Change and Conflict}

An adjunct to the study of climate induced migration is the study of the relationship between climate change and violent conflict. This field is also not without criticism or controversy, once again relating to the post-hoc nature of the inquiry (Buhaug, 2015). However, in terms of quantifying a link between climate change and human migration - specifically refugees - this realm appears to be more instructive in relation to the premise of this paper.

Geo-spatial and statistical inquiries into the relationship between environmental conditions and conflict events are useful in revealing linkages. For example, O'Loughlin et al. (2014) found a correlation between temperature extremes and violence in Sub-Saharan Africa from 1980 to 2012 - though the study notes that economic, political and social indicators were better predictors of conflict. Similarly, Raleigh \& Urdal (2007) found links between land degradation, water scarcity and the potential for an area to experience violent conflict. Interestingly, their study indicates that the best predictor of armed conflict is population density at lower spatial levels and declining GDP at higher spatial levels. Finally, Reuveny \& Barbiery (2014) used a multi-variate regression analysis to examine the effect natural resource availability has on the probability that any one country may experience war. The results of their analysis indicate that warfare becomes more probable in nations with larger populations, declining GDP, and those that experience increase in the frequency and intensity of weather events. Climate change is expected to impact all of these factors. For example, permanently migrating to urban centres in the global south may become a coping mechanism for households vulnerable to climate change (Findlay, 2011), which could lead to volatility as these cities struggle to cope with influxes of displaced populations (Reuveny, 2007; Wodon et al., 2014). Globally, GDP is expected to decline if climate change is left unaddressed (Stern, 2007), while weather events across the planet are likely to become more variable in their 
intensity and frequency (IPCC, 2015). Of course, statistical models cannot be absolute predictors of the future (McLeman 2013). Moreover, the statistical links between environmental conditions and warfare are tenuous (Buhaug et al., 2008) and there are issues in identifying causality between events that are variable in both spatial and temporal scales (Bettini \& Andersson, 2014). Climate change as a threat multiplier is not a new discourse (Brown \& McLeman, 2009) and neither are its criticisms. As Matthew (2011) points out, the relationship between conflict and climate change is an "admixture of confidence and uncertainty that allows it to be integrated into any political agenda" (p. 60). Yet policymakers and NGO's appear to be taking such predictions seriously. The National Intelligence Council (NIC) of the United States in their 2030 outlook foresee an increase in violence and conflict across the globe as a result of climate change (NIC, 2012). Background papers from the World Bank (Evans, 2011; Raleigh et al., 2008) draw similar conclusions, while the IPCC (2015) also generally agrees with this premise. Outside of academic debates, there appears to be agreement among national and international actors that climate change will, indirectly and over time, increase violence and conflict, leading to a potential growth in refugee populations.

\section{Future Scenarios}

From the research studied, it appears that climate change will aggravate existing or simmering conflicts and trigger migration flows should the conflicts escalate; though the extent to which climate change will foster such crises is still unknown and unquantified. From a purely statistical perspective, the likelihood of armed conflict is greater for states with a shortage of water and arable land and with high localized population densities. Moreover, literature indicates that the probability of these factors developing within nations over the next century will grow as climate change begins to affect global GDP and weather patterns, although a complex array of 
other causal factors for these conflicts cannot be discounted nor ignored (Buhaug 2008; Meierding, 2013). However, recent events indicate that this type of climate-induced conflict aggravation may already be occurring. For example, Gleick (2014) draws a link between the mismanagement of water supplies, agricultural failure, and unprecedented rural-urban migration ${ }^{6}$ in Syria to its protracted civil war. Other scholars have traced the roots of the 2011 "Arab Spring" to crop failures and global drought conditions that were likely exacerbated by climate change (Johnstone \& Mazzo, 2011). Future conflicts may be looming on the horizon: Greenwood (2014) and Wodon et al. (2012) both outline the challenges many Arab countries are currently facing due to water mismanagement and dry conditions exacerbated by climate change. The future, apparently, is now.

A final note of caution on drawing a line between climate change, conflict and migration. As Hartmann (2010) points out, regardless of whether climate change will cause mass migration events, it is dangerous to point to environmental determinism as a blanket cause or trigger when many other factors are at play. Likewise, Bettini (2014) describes how the discourse in both academic and scientific realms on the subject of climate change and migration has shifted from that of an alarmist scenario to a more nuanced understanding of the factors that affect migration. However, he points out that in some policy papers this discourse has morphed into a re-positioning of neo-liberal relations with marginalized populations in the global south; for instance, managing the "docile and mobile" (ibid: p. 189) climate migrant and their movements in order to facilitate entrepreneurship and economic growth. ${ }^{7}$ In effect, using climate change induced migration as a vehicle to fit the marginalized into market activities. He advocates for international efforts that move away from attempting to govern a migration crisis that may-or-may-not occur towards

\footnotetext{
${ }^{6}$ It is estimated that 40,000 to 60,000 Syrian households in affected areas moved in response to the 2006-2009 drought (DREF 2009) with the majority ending up in urban centres.

${ }^{7}$ See Black et al., 2011a for an example.
} 
policies that help communities in the global south adapt and mitigate in situ. Given the political currency that forced displacement due to climate change has induced so far, and the closing of borders and increasing surveillance by the global north against real or perceived migrant flows, ${ }^{8}$ these are salient points to keep in mind as the world enters a century where economic, social and climatic systems are about to interact in unprecedented ways.

\footnotetext{
${ }^{8}$ There is a growing body of literature that critically analyzes the framing and discourse of migrants and climate change. See: Methmann \& Oels (2015); Hartmann (2010); Ransan-Cooper (2015); and Baldwin (2016) for examples.
} 


\section{Canadian Refugee Policy: Past and Futures}

Canada is often credited as having one of the most progressive and generous refugee policies in the west. However, it has not always been so. Canadian openness to refugee resettlement has been a recent development, and the country has a considerable and painful history of racist and exclusionary policy (Abella, 1993; Knowles, 2007). Yet for better or worse, this is also indicative

of Canada's flexibility with refugee policy regimes. Given a lack of international regimes to classify or categorize potential environmental migrants, it is prudent to conceptualize how future migration flows resulting directly or indirectly from climate change could be handled within existing refugee policies in Canada.

\section{A Brief History of Refugee Asylum in Canada}

Canada's refugee policy has oscillated between exclusionary and welcoming over the past century. Refugee asylum policy in Canada prior to World War II was generally racist and discriminatory. 'Refugees' were typically populations of displaced European agriculturalists that were actively sought by the federal government for resettlement in the Canadian west (Abella, 1993). Non-white asylum or immigration was routinely discouraged or punitively dealt with through racist policy. The refusal of asylum to 376 Punjabi-Sikh refugees (all of whom were British subjects) arriving by steamship off the coast of Vancouver in 1914 is exemplary of the political and social mindset of the time (ibid.). Policies relaxed somewhat in the 1930s and 'nonpreferred' classes of individuals began to trickle in, although ethnicities other than European were still prohibited (Knowles, 2007). This gradually accelerated during and after the second world war with consecutive waves of Jewish and Eastern European refugees arriving to resettle in Canada, including 37,000 Hungarians in 1956. It was only until the 1960s that the nation's discriminatory immigration policies officially ended (Abella, 1993). Formal recognition of 
refugees as a separate class of immigration came with the passage of the Immigration Act of 1976. This Act also reaffirmed Canada's legal obligation to the United Nations Convention Relating to the Status of Refugees of 1951 and its Protocol of 1967, both of which Canada signed in 1969. The landmark Singh decision of 1984 guaranteed refugee claimants the same rights as Canadian born citizens under the Charter of Rights and Freedoms (Government of Canada, 2011). Despite advancements, recent developments point to a more exclusionary stance in Canadian refugee policy: in 2012, the assent of Bill C-31 Protecting Canada's Immigration System Act stratified refugee claims into two streams via a Designated Country of Origin (DCO) policy. The DCO allows the Government of Canada to identify countries that respect human rights, offer protections and do not usually produce refugees. Refugees from designated DCO countries have their asylum claims processed and expedited, but do not have access to the Refugee Appeal Division should they be denied (Government of Canada, 2010). Critics of the DCO argue that the policy is exclusionary and discriminatory, as it disallows a right of appeal and limits opportunities for refugees from DCO's to access employment and healthcare during the determination process (Hari, 2014). In July, 2015 a Federal Court agreed that the DCO was discriminatory, and the prohibition of appeals to the Refugee Appeal Division by refugees from DCO's was ruled unconstitutional (Keung, 2015). What is evident from this brief history is that although Canada has been relatively progressive in its refugee policy, the system is malleable and subject to interference. This has certain benefits, as it can be reactive to crisis, but also has considerable drawbacks, as it can easily be made discriminatory. These issues are explored further in the next section. 


\section{Current Canadian Refugee Policy}

Canada currently admits newcomers under three classifications: economic, family and refugee. The refugee class is further stratified into two programs: The Refugee Humanitarian Resettlement Program and the In-Canada Asylum Program (Government of Canada, 2008).

Refugees in the Refugee Humanitarian Resettlement Program are essentially sponsored refugees. They are either identified overseas through a private group such as a family, or through the Canadian government. Once identified, these refugees are flown to Canada and given permanent residency as well as assistance from the Government or their sponsors. A separate stream within this category are refugees taken in under the Blended Visa Office-Referred (BVOR) program, which matches refugees with private sponsors in Canada through the UNHCR.

Refugees in the In-Canada Asylum program claim asylum in Canada. These individuals are not given permanent residency; rather, they must take their claim through a refugee determination process, which may take months. However, during the refugee determination process, claimants are given access to education, employment and, as of April 2016, ${ }^{9}$ medical care.

Within the Refugee Humanitarian Resettlement Program are two classes: Convention Refugee Abroad Class and Country of Asylum Class. The Convention Refugee Abroad Class consists of individuals outside of their country of residence who cannot return due to fear of

\footnotetext{
${ }^{9}$ Under the Harper government, medical benefits given to refugee claimants under the 59-year-old Interim Federal Health Program were cut in June, 2012. These cuts have since been reversed by the Trudeau government, with the promise of expansion to cover healthcare costs that arise before a refugee arrives in Canada, e.g. vaccinations, medical exams, and disease management (Goar, 2016). Although a step forward, this policy back-and-forth is illustrative of the politicization of refugee settlement in Canada.
} 
persecution. The Country of Asylum Class consists of individuals outside their country of residence who cannot return due to civil war, armed conflict, or human rights violations.

Canada admitted around 23,300 refugees in 2014 (Citizenship and Immigration Canada [CIC], 2014). Around 7,500 of these were government sponsored and 4,500 were privately sponsored. There were a total of about 13,400 refugee claimants in 2014, with China as the primary source country. This is around 23,400 less refugee claimants than the peak in 2008, and 10,000 less than the running average for the past decade. In fact, the amount of refugees admitted into Canada annually is around 12,500 less in 2014 than it was ten years ago in 2005, likely due to the DCO policies introduced in Bill C-31 as discussed earlier (Keung, 2013).

International and domestic pressure in response to high-profile events have been significant catalysts for a number of major refugee resettlement initiatives in Canada (Abella, 1993; Knowles, 2007). International obligations, extensive media coverage, and agitation by domestic organizations appear to be key determinants to whether the Government of Canada will respond to an overseas refugee crisis. Two early examples include the 37,000 Hungarians resettled after a failed Hungarian uprising in 1956 and the 12,000 Czechs resettled after a similar revolt failed in Prague. More recently, 50,000 Vietnamese refugees were resettled in Canada as a result of public outcry to the horrors of the Vietnam war (Abella, 1993); while 5,000 Bosnians were granted asylum during a period of ethnic cleansing in Yugoslavia in the 1990's (Knowles, 2007). Using the federal response to the displaced people of the 2011 Haitian earthquake as an example, Omeziri \& Gore (2011) point out that while the ad-hoc nature of Canada's refugee policy offers certain flexibilities in terms of quickly expediting large numbers of refugees for resettlement, it faces serious drawbacks in terms of crafting the type of coherent, long-term refugee strategy that might be needed if the world faces a serious migration crisis. Moreover, 
they argue that this ad-hoc 'wait and see' approach is an essential part of Canadian refugee policy. Similarly, Murray (2010) reflects that while the recent history of Canadian refugee policy has had moments of generosity, it is also subject to "sophistry" (p. 53) on the part of politicians and officials. In light of this, the current intake of 25,000 Syrian refugees into Canada seems to be a continuation of this trend, as it was apparently spurred by politics and public outcry. ${ }^{10}$ Going forward, both Omeziri \& Gore (2011) as well as Murray (2011) appear skeptical that there will be any substantive change to these practices on the Federal level, barring a major shift in public attitude or a global crisis. Given this, how would Canada respond to a migration crisis caused by climate change under current refugee policy?

\section{Environmental Migrants and Canada's Refugee Regime}

Displacement due to climate change or environmental degradation is not currently a category for claiming asylum within Canada's refugee determination system (Murray, 2010; Government of Canada, 2008). Yet the absence of this category does not preclude nor diminish eventual migration flows into Canada as the result of climate change. Climate change as a threat multiplier will, statistically, lead to more conflict events across the planet. These events will lead to more individuals fleeing their homes due to violence - which, under the Country or Asylum class of the Refugee Humanitarian Resettlement Program, is an eligible reason to be resettled in Canada. In the political realm, unless there are changes in national policy, the Federal

\footnotetext{
${ }^{10}$ In September, 2015 a photograph of a drowned Syrian boy, Alan Kurdi, on a Greecian beach became a defining image of the Syrian refugee crisis. In Canada, a concurrent Federal election campaign was suddenly refocused onto Canadian refugee policy once it was revealed that Alan's family had been refused asylum by the Harper government (Kestler-D'Amours, 2015). The response by all Canadian federal political parties to the sudden public outcry over Alan's death was to promise ever greater numbers of Syrian refugees to be resettled in Canada. The incumbent Conservative Party promised to double the amount of Syrian refugees to 20,000 over three years; the opposition NDP promised to accept 10,000 by the end of 2015; while the third place Liberal Party of Canada pledged to have 25,000 Syrians resettled in Canada by the end of the year (Hall, 2015). On October 19th, 2015, the Liberal Party of Canada won the Canadian federal election and formed a majority government; its first in over a decade.
} 
government is likely to respond to these new refugee crises in a manner similar to the way it has responded in the past: that is, in an ad-hoc fashion and catalyzed through a variety of domestic and international pressures (Omeziri \& Gore, 2011; Murray, 2010). Therefore, it is reasonable to assume that climate change will indirectly result in an increase in the frequency and scale of future refugee intake episodes in Canada, or, at minimum, result in an increase in the frequency that Canada is asked to admit people displaced.

Given this assumption, climate change generated refugee flows to Canada are likely to look similar to existing and recent episodes of refugee resettlement within current policy regimes. That is, households will acquire settlement in Canada through government and private sponsorship, not through asylum claims. This is true for the current Syrian refugee intake, which by itself has doubled the annual amount of refugees taken in nationally and by category has dramatically overshadowed annual refugee claimants. Those claiming asylum in Canada as the result (directly or indirectly) of climate change are not likely to increase, as the process generally requires refugees to first step foot in Canada and then claim asylum - a process which would be very difficult if those displaced by climate change are the globally impoverished. That does not mean an increase in claimants is unlikely: there could be a flow of wealthy individuals who have the means to leave their place of origin due to climate change. Moreover, some of the more hyperbolic and alarmist predictions of our future climate envision a mass population exodus northward from the United States and Mexico (Giles, 2013). However, any future asylum claims of this nature would be dependent on the federal government adding environmental degradation to its list of credible reasons for seeking asylum in Canada, as well as the modification or elimination of Designated Country of Origin policies. One would also hope that policymakers would take considerable action 
on climate change well before a scenario of mass population movement from southern regions into Canada would occur. 


\section{Refugees and Newcomers in Metropolitan Toronto}

For future refugees that arrive in Canada as the result of climate change, the GTA will likely be one of the first places considered for settlement. Today, Toronto is the main point of entry for immigrants and refugees upon their arrival in Canada, and metropolitan Toronto is where many eventually choose to make their home (Preston et al., 2011; OCASI, 2012). An understanding of the spatial distribution and experiences of newcomers and refugees is therefore a key part in planning for any future episodes of refugee settlement.

\section{The Context of Ethno-Cultural Diversity in Metropolitan Toronto}

Metropolitan Toronto is popularly constructed as one of the most ethnically diverse urban conglomerations in North America. Within the Toronto CMA, at least 160 languages are spoken (The City of Toronto, 2012) and over $48 \%$ of the population is foreign born (Government of Canada, 2013). Yet this is not a new trend. Toronto has been a primary point of settlement for most of its history, beginning with waves of European migration before the second world war. Once immigration restrictions and reformed by the federal government starting in the 1960s, the metropolitan Toronto region became a magnet for households globally. Today, several municipalities in the GTA are majority-minority areas where more than $50 \%$ of their population identify as a visible minority (Preston et al., 2010; Tolley \& Young, 2011). Demographics across the GTA have shifted dramatically in the past three decades as the result of a federal immigration policy that has focused on recruiting skilled workers, reunifying families, and providing resettlement for refugees under international obligations. This multitude of diversity has fundamentally shaped the form of the city over time: many older immigrant-receiving neighborhoods are referred to by the ethnic composition of residents, even if the ethnic group has long since ceased to make up a significant part of the local population (e.g. Corsa Italia, 
Greektown, Chinatown, Koreatown), while in the suburbs, new developments such as Pacific Mall in Markham are built specifically for the needs of the surrounding ethnic community by being constructed and operated in a way that reflects their cultural practices (Zhuang, 2013).

Yet while the GTA as a whole is becoming more diverse, urban areas within it are becoming more ethnically homogenous. The development of "ethno burbs" - peripheral suburban areas consisting of a plurality of ethnic groups with one ethnic minority group in significant concentration - has accelerated over the past two decades, largely due to the tendency for newcomers and aspiring immigrants to settle in suburbs outside historic ethnic inner-city districts (Good, 2009). A study by Qadeer et al. (2010) outlines the process of how ethno burbs in the GTA develop. Initially these areas begin with a core of households that act as clusters. Over time, these clusters gradually consolidate and attract additional households. These clusters then begin attracting services, businesses and institutions. This dynamic creates new opportunities to reinvent the traditional built form of the suburbs, but also has significant costs in terms of mobility and accessing the needs of everyday life, especially for new arrivals with limited means (Wood et al., 2011).

The research by Qadeer et al. (2010) has implications for the future ethnic composition of the GTA. Projections of existing trends by Hiebert et al. (2012) on the ethno cultural makeup of metropolitan Toronto in 2031 describe a region that is simultaneously minority-majority and increasingly segregated. Continued spatial concentration of visible minorities, such as the process described by Qadeer et al. (2010), will likely end up forming concentrated ethnic enclaves where one ethnic group will make up virtually the entire population. Non-visible minorities will not be immune to this process and will eventually spatially sort themselves into "whiter" districts. As Hiebert et al. (2012) notes, this analysis describes a scenario of segregation that is borne out of 
individual household decisions rather than state coercion or interference; in effect, it is market based segregation behaviour that is unprecedented in modern times. Yet this is not to say that such districts will become "ghettos" or economically disadvantaged. In fact, economic vibrancy is often a hallmark of these areas and will likely remain so into the future, so long as policy and planning support the vitality of these communities (Qadeer et al., 2010; Hiebert, 2015). Suburban municipalities will inevitably have to adapt planning policies for future populations that may expect or demand different land-use regimes and built environments.

\section{Refugee Settlement: Planning Issues}

Two issues related to land-use planning that are of considerable urgency for refugees who settle in the GTA: housing and access to services. While there is a growing body of scholarship on the settlement experiences of refugees and newcomers in Toronto (See: Murdie, 2003, 2008, 2010; Dippo et al., 2013; Preston et al., 2010, 2011), very little exists for refugees who have settled in suburban municipalities outside of the City of Toronto. Nevertheless, existing studies within Toronto indicate that affordable housing remains the most pressing issue facing refugee households. For refugees, precarious housing is often a fact of life (Francis \& Hiebert, 2014; Preston et al., 2011). Homeownership is rare, and refugees generally do not become homeowners (Murdie, 2010). Moreover, although refugee housing outcomes generally improve over time, they tend to be generally worse overall than other immigrant groups (Murdie, 2008). The cost and quality of housing has often been cited in interviews as a factor for settlement decisions, leading to dissatisfaction with neighborhoods (Carter et al., 2009) and more instances of relocation from one housing unit to another (Preston et al., 20011). These can have significant impacts on integration and can push a household towards homelessness (ibid.) 
The affordability issue faced by refugees is born out by statistics. Rental supply in the GTA has not increased by any appreciable metric over the past decade, while rental rates have continued to outpace inflation and wage growth. In 2015, average vacancy for purpose built rental structures was $1.6 \%$, while across the GTA average rents increased by $3.3 \%$ year-over-year (Canada Mortgage and Housing Corporation [CMHC], 2015). Larger 3 bedroom units suitable for families and children continue to be in high demand as a consequence of households delaying the purchase of a new home due to an overheated housing market. This is reflected in the average rents for these units, which are generally well above the metropolitan average (Ontario Ministry of Housing, 2015). Refugees also face issues of discrimination within the private market during their housing search. For example, the experience of newly arrived Portuguese-speaking Angolan refugees within the Portuguese community in Toronto was tinged with racism, affecting their ability to successfully acquire housing and forge social ties despite sharing a common language and colonial history (Teixeira, 2008).

It is also important to recognize that housing is much more than shelter. A place to live, a 'home,' is imbued with value and meaning for the occupier. In the GTA, western housing arrangements are often modified by newcomers according to cultural practice. For example, Logan \& Murdie (2016) outline the cultural practices that have continued to persist among Tibetan refugees in Toronto's Parkdale neighborhood despite crowded living quarters and affordability issues. Mensah and Williams (2013) in their study of black Africans in Toronto's housing market explore how some cultural practices are either discarded or modified in order to fit within the constraints of western housing arrangements, such as the abandonment of traditional meals due to limitations in the layout of western kitchens. 
Transportation and access to services has also been identified as a key problem for refugees (Makwarimba et al., 2013; Murdie \& Ghosh, 2010). In a 2012 study on newcomer access to services by the Ontario Council of Agencies Serving Immigrants (OCASI), over half of respondents indicated they utilize public transit. In that same report, distance of housing to services was identified by almost all respondents as a critical barrier in being able to utilize them. In urban planning, it is generally accepted that low-density, auto-oriented development has a negative impact on social interaction and community building, along with significant externalized costs in terms of service provision and environmental impacts. Urban or suburban areas where such development is prevalent often have the lowest housing costs and may be the best option for a refugee household to settle based on fiscal constraints. Yet for those who are do not possess the legal or financial means to operate an automobile, this type of built environment could disadvantage their access to services, institutions and employment, as well as inhibit their ability to form social capital. 


\section{Multicultural Planning: A Direction for the Future?}

Canada will likely experience an increase in the frequency and scale of refugee flows due to the effects of climate change, and municipalities within the GTA will need to cope with the prospect of sudden and unforeseen influxes of newcomers with diverse cultural backgrounds. For planners in Ontario, this issue has implications for our built environment. As the Syrian refugee intake has demonstrated, where and how refugees resettle has become an urgent question. Moreover, many of the problems refugees face in resettlement touch directly upon issues of landuse planning. In the absence of any official policies or directives from policymakers with regards to this topic, I suggest that planners build the capacity for communities to handle episodes of refugee resettlement by integrating methods of multicultural planning into their practice.

Although multiculturalism is an official policy at the federal level, ${ }^{11}$ it has yet to be incorporated into municipal planning regimes in the GTA. The City of Toronto, although having established multiculturalism policy at the institutional level (Good, 2009), still struggles to incorporate multiculturalism within planning practices (Zhuang, 2013). Suburban municipalities, such as Markham and Mississauga, have been slow in addressing or incorporating multiculturalism into municipal policy (Good, 2009; Tolley \& Young, 2011). In fact, an examination of Official Plans for municipalities in Halton, Peel, York and Durham regions reveals how little multiculturalism has been formalized into land-use planning. Out of twenty-nine Official Plans, just two contained the words 'multicultural' or 'multiculturalism', and only then as a descriptor rather than a policy direction. This finding is much more discouraging in light of a recommendation

\footnotetext{
${ }^{11}$ The policy of the Multiculturalism Act recognizes the freedom for all citizens "... to preserve and enhance their cultural heritage" (Canada, 1988: 3(1)(a)) while also promoting "...the full and equitable participation of individuals and communities of all origins in the continuing evolution and shaping of all aspects of Canadian society" (Canada, 1988: 3(2)(c)).
} 
made over twelve years ago by Wallace \& Milroy (2004) to include multiculturalism as part of official plan policies.

Multiculturalism can be extremely useful in accommodating and engaging diverse populations (Wallace \& Milroy, 2004; Wood \& Gilbert, 2009), something that will be necessary should more refugee episodes bring an influx of new residents to the GTA. Yet this is also dependent on multiculturalism becoming multi-scalar and cross jurisdictional. As Good (2009) points out, "If multiculturalism policies are to continue to be effective, they must address the geographic and jurisdictional dimensions of multiculturalism" (p. 10). Incorporating existing multiculturalism policy into land-use planning practices would make a direct connection between federal and municipal governance regimes while also addressing the disparity of geographic scale in multicultural policy - that is, the disparity between its intentions as national policy and the outcomes it achieves at local levels. Multiculturalism in planning practice would also give communities within the GTA the tools necessary to tailor the built environment in a way that can anticipate, accommodate and reflect future refugee resettlement needs. To entwine multiculturalism into land-use planning, Qadeer (2009) outlines four ways that planning and professional planners can incorporate multiculturalism into policy and practice:

1) Ethnic communities should have a voice within the planning process;

2) Cultural practices at both the individual and group/community level should be addressed by planning regimes and practice;

3) Services should be administered in culturally sensitive ways, and;

4) Planners should recognize the ongoing way in which people and places mutually shape one another. 
Using this is as a framework, I will lay out several brief recommendations as to how incorporating multicultural planning could better prepare municipalities within the GTA for future refugee flows that may directly or indirectly result from the effect of climate change.

\section{Adding Voices to the Planning Process}

Even the most proactive planning processes can miss the mark when it comes to engaging ethnic communities (Zhuang, 2013), and planners may need to start utilizing diverse or unorthodox methods of engagement in order to bring underrepresented populations to the table. The voices of resettled refugees, both now and in the future, should be brought into these discussions. The needs of refugees intersect with urban spaces in complex ways, and positive outcomes are often linked to the geography of the settlement process (Wood et al., 2012). We should strive to understand and engage refugees on how the city and the built environment affect or influence them. Doing so may call for different ways of engaging these communities. For example, planners could develop strategies to engage refugees through collaboration with settlement service providers. Another strategy could be to perform ethnographic studies of how refugees interact with and perceive the spaces of their community. However, careful consideration and reflection should occur when deciding upon an engagement strategy. For instance, a form of expression that seems respectful to a planner or community member may not be taken as such by the other party. Planners should be sensitive and understanding of the cultural differences that may exist in communication, and should make use of local or in-house knowledge of communities to inform outreach strategies.

\section{Addressing and Anticipating Cultural Differences}

For implementing multiculturalism into planning, it is vital to become mindful and informed of the cultural dimensions of the communities we interface with. Planners should pay 
especially close attention to emerging cultural trends in local land-use and demographics, as future populations will likely make different demands of traditional land-use forms. For some ethnic groups, the typical suburban bungalow, although aspirational, may not be adequate for their needs. There may be a significant disconnect between western-style living arrangements and the living arrangements desired by the households of some ethnic groups (see Mensah \& Williams, 2014). This discrepancy of use could spill over into planning processes and cause confrontation (Qadeer, 2009). For instance, in Peel region, although residential areas are primarily comprised of detached homes, the proportion of households with multiple families has doubled since the 1970's (Agrawal, 2010). This is due to the cultural needs of South-Asian households, which emphasize multiple generations living together in the same home (ibid). These type of trends have implications for a range of planning topics, including floor-to-area ratio allowances in residential areas, frequency and type of transit service, the siting of new community services, and on-street parking and minimum parking requirements, among others. As detached homes will continue to comprise the majority of new residential growth between now and 2041 in the regions adjacent to the City of Toronto (Government of Ontario, 2013), it would be prudent to investigate whether cultural needs are being met through existing planning policy and development, and especially whether the needs of refugee and other immigrant households are being addressed. Current regimes of zoning bylaws and secondary plans may be insufficient to adequately negotiate land-use issues arising from a sudden or unanticipated influx of new households into the GTA. Building in flexibility through targeted policy in specific communities or adopting new innovative ways of managing development, such as a form-based zoning code that regulates physical form rather than segregating uses, are some of the ways planners could proactively address such challenges. 


\section{Emphasizing Diverse Services for Communities}

Quickly establishing and maintaining social capital is vital for positive social and economic outcomes for refugees (Lamba \& Krahn, 2003), and much of this is dependent on where refugee households end up settling. A lack of affordable housing and the proximity of housing to services continue to be critical issues for refugees in the GTA. Moreover, the physical environment can play a key part in making a newly arrived refugee household feel integrated and included within the host society (Wood et al., 2012). Planners should encourage the development of new affordable housing programs that can address the fiscal and cultural needs of refugees. Development and infrastructure that encourages walking, cycling and public transportation should also be considered a priority for planning policy. Reducing car dependence and increasing the prevalence of alternate modes of transportation ensures that refugees and newcomers can access services, employment and the needs of day-to-day life without facing barriers to mobility. For example, providing an increase in the non-peak period frequency of a bus route through a neighborhood with a high proportion of refugees can give households more mobility options and increase their standard of living. Alternatively, creating an integrated network of cycle tracks or protected bike lanes and mandating bicycle infrastructure can give households the freedom to travel long distances without having to own an automobile or rely on the schedules of a transit agency.

\section{Becoming Agents of Change}

Planners must take initiative on gathering data, conducting research, and shaping policy in order to address the needs of newcomers and refugees. Planners are experts on understanding the linkages between populations and land-use, and have a multitude of tools available to tackle or anticipate future challenges. For example, planners in Peel region have been proactive in 
undertaking extensive demographic analysis of newcomer populations and research on the challenges and opportunities for incorporating new immigrants into the region's planning process (Tolley \& Young, 2011; Agrawal, 2010; Bernhard et al., 2010). For suburban municipalities where policymakers have been slow or indifferent to incorporating multiculturalism into planning regimes, there is significant room for planners to act as agents of change. The first step in such a process would be to acquire data and conduct research on settlement patterns, demographic trends and community needs. Within this space there may also be room to go beyond jurisdictional boundaries. Planners could look beyond city halls and towards Ottawa and liaison with the federal government to better prepare cities for future refugee resettlement episodes. For instance, a planner could cultivate relationships with service providers and the federal government to map and identify areas where refugees are being settled. Looking ahead to future episodes of refugee resettlement by the Canadian government, such information could go a long way in reducing the type uncertainty and difficulty faced by service providers in resettlement as seen with the Syrian refugee intake (Reynolds \& Goffin, 2016).

Finally, for planners working in metropolitan Toronto and across Canada, it is important to be aware of the interactions and intersections between global events and local outcomes. With conflicts like Syria likely escalating over the next century due to the 'threat multiplier' of climate change, and with a reactionary Canadian refugee policy leading to more episodes of refugee intake as a result, planners in the Toronto metropolitan region should begin to think about how land-use policy and planning can support the flexibility necessary to resettle these future pulses of newcomers. 


\section{Conclusion}

Climate change will have unknown and variable effects on human migration patterns. Yet despite the uncertain empirical links between environmental degradation and population displacement, there appears to be a general sense in policy papers and academic literature that a global migration crisis is entirely feasible and not beyond the realm of plausibility. Assuming no changes in ad-hoc federal refugee policy, Canada will certainly become a future home for episodes of displaced peoples, whether they result directly or indirectly from climate change. As one of the most diverse cities in North America and as one of the primary points of entry for newcomers, the GTA can expect to welcome a considerable number of these households. Planners working in the region, especially those in minority-majority suburban municipalities around the City of Toronto, should be prepared to take a lead role in addressing the challenges associated with this issue. Within this context, multicultural planning offers a useful framework for land-use policy and planning to become flexible and proactive in responding to the needs of existing and future refugees. We are lucky to live in a part of the world that will no doubt become a beacon of stability over the next century and beyond. It is crucial that we begin to imagine what the potential outcomes of this will be for our cities, regions and communities. 


\section{References}

Abella, I. (1993). Canadian Refugee Policy to 1980. In V. Robinson (Ed.), The International Refugee Crisis: Canadian and British Responses. 77-94. London: Macmillan.

Arctic Climate Impact Assessment [ACIA]. (2005). Impacts of a Warming Arctic: Arctic Climate Impacts Assessment. Cambridge University Press, Cambridge, 1042 pp.

Agrawal, S. K. (2010). Neighbourhood patterns and housing choices of immigrants. Region of Peel, Human Services. Retrieved from https://extinguishthesource.ca/social-services/pdfs/discussionpaper-4.pdf

Baldwin, A. (2016). Premediation and white affect: climate change and migration in critical perspective. Transactions of the Institute of British Geographers, 41(1), 78-90.

Bernhard, J. K., Hyman, I., \& Tate, E. (2010). Meeting the Needs of Immigrants Throughout the Life Cycle. Region of Peel, Human Services. Retrieved from https://peel.ca/socialservices/pdfs/discussion-paper-2.pdf

Bettini, G., \& Andersson, E. (2014). Sand Waves and Human Tides: Exploring Environmental Myths on Desertification and Climate-Induced Migration. The Journal of Environment \& Development, 23(1), 160-185.

Bettini, G. (2013). Climate Barbarians at the Gate? A critique of apocalyptic narratives on "climate refugees." Geoforum, 45, 63-72.

Bettini, G. (2014). Climate migration as an adaption strategy: de-securitizing climate-induced migration or making the unruly governable? Critical Studies on Security, 2(2), 180-195.

Black, R., Adger, W. N., Arnell, N. W., Dercon, S., Geddes, A., \& Thomas, D. (2011). The effect of environmental change on human migration. Global Environmental Change, 21, S3-S11. 
Black, R., Bennett, S. R., Thomas, S. M., \& Beddington, J. R. (2011). Climate change: Migration as adaptation. Nature, 478(7370), 447-449.

Brown, O., \& McLeman, R. (2009). A recurring anarchy?: The emergence of climate change as a threat to international peace and security. Conflict, Security and Development, 9(3), 289-305.

Buhaug, H. (2015). Climate-conflict research: some reflections on the way forward. Wiley Interdisciplinary Reviews: Climate Change, 6(3), 269-275.

Buhaug, H., Gleditsch, N. P., \& Theisen, O. M. (2008). Implications of climate change for armed conflict (Paper presented to the World Bank workshop on Social Dimensions of Climate Change). Washington, D.C.: The World Bank.

Canada. (1988). Canadian Multiculturalism Act, 21 July.

Canada Mortgage and Housing Corporation [CMHC]. (2015). Rental Market Report: Greater Toronto Area. Ottawa: Government of Canada.

Carrington, D., \& Slezak, M. (2016, March 14). February breaks global temperature records by “shocking” amount. The Guardian. Retrieved from https://www.theguardian.com/science/2016/mar/14/february-breaks-global-temperature-recordsby-shocking-amount

Carter, T. S., Polevychok, C., \& Osborne, J. (2009). The role of housing and neighbourhood in the resettlement process: a case study of refugee households in Winnipeg. Canadian Geographer / Le Géographe Canadien, 53(3), 305-322.

Chan, S. (2015, December 12). Paris Accord Considers Climate Change as a Factor in Mass Migration. The New York Times. Retrieved from http://www.nytimes.com/2015/12/13/world/europe/paris-accord-considers-climate-change-as-afactor-in-mass-migration.html 
Chen, R. J. (2011). Effects of Climate Change in North America: An Overview. Journal of Sustainable Development, 4(3).

Christian Aid. (2007). Human Tide: The Real Migration Crisis. London: Christian Aid.

Citizenship and Immigration Canada [CIC]. (2014). Facts and figures: immigration overview permanent and temporary residents. Ottawa: Citizenship and Immigration Canada, Research and Evaluation Branch.

The City of Toronto. (2012, October 25). Backgrounder - 2011 Census: Language. City of Toronto Social Policy, Analysis \& Research.

The City of Toronto. (2011). Toronto's Future Weather and Climate Driver Study Volume 1. Toronto: City of Toronto.

Colombo, S. J., Ontario, Ministry of Natural Resources, \& Applied Research and Development. (2007). Climate change projections for Ontario practical information for policymakers and planners. Sault Ste. Marie, Ont.: Applied Research and Development Branch, Ontario Ministry of Natural Resources.

Crozier, L. G., Hendry, A. P., Lawson, P. W., Quinn, T. P., Mantua, N. J., Battin, J., Huey, R. B. (2008). Potential responses to climate change in organisms with complex life histories: evolution and plasticity in Pacific salmon. Evolutionary Applications, 1(2), 252-270.

Diamond, J. (2005). Guns, Germs, and Steel: The Fates of Human Societies. New York: Norton.

Diaz, H. P., Kulshreshtha, S. N., Sauchyn, D. J., \& University of Regina (Eds.). (2010). The new normal: The Canadian prairies in a changing climate. Regina, Sask: CPRC Press.

Dippo, D., Basu, R., \& Duran, M. (2013). Settlement and Schooling: Unique Circumstances of Refugees and Forced Migrants in Post-War Toronto Suburbs. Canadian Ethnic Studies, 44(3), 
DREF Operation. (2009, August 3). Syria: Drought. International Federation of Red Cross and Red Crescent Societies.

Dyer, G. (2008). Climate Wars. Toronto: Random House Canada.

Evans, A. (2011). Resource scarcity, climate change and the risk of violent conflict. New York: New York University.

Findlay, A. M. (2011). Migrant destinations in an era of environmental change. Global Environmental Change, 21, S50-S58.

Francis, J., \& Hiebert, D. (2014). Shaky foundations: Refugees in Vancouver's housing market: Shaky foundations. The Canadian Geographer, 58(1), 63-78.

Gemenne, F. (2011). Why the numbers don't add up: A review of estimates and predictions of people displaced by environmental changes. Global Environmental Change, 21, S41-S49.

Giles, S. (2013). American Exodus: Climate Change and the Coming Flight for Survival. Gabriola, BC: New Society Publishers

Gleck, P. (2014). Water, Drought, Climate Change, and Conflict in Syria. Weather, Climate and Society, 6(3), 331-340.

Goar, C. (2016, February 24). Cancellation of refugee health benefits forces doctors to put down their stethoscopes and take up placards. The Toronto Star. Retrieved from http://www.thestar.com/opinion/commentary/2016/02/24/lessons-from-canadas-refugee-healthsaga-goar.html

Good, K. R. (2009). Municipalities and multiculturalism: the politics of immigration in Toronto and Vancouver. Toronto: University of Toronto Press.

Government of Canada, C. I. C. (2010, March 30). Designated countries of origin. Retrieved March 19, 2016, from http://www.cic.gc.ca/english/refugees/reform-safe.asp 
Government of Canada, C. I. C. (2008, June 19). The refugee system in Canada. Retrieved March 19, 2016, from http://www.cic.gc.ca/english/refugees/canada.asp

Government of Canada, C. I. C. (2011, June 20). Canada: A History of Refuge. Retrieved March 19, 2016, from http://www.cic.gc.ca/english/refugees/timeline.asp

Government of Canada, Statistics Canada. (2013, May 8). Toronto (City) - Focus on Geography Series - 2011 National Household Survey (NHS).

Government of Ontario. (2013). Technical Report Addendum to the Greater Golden Horseshoe Growth Forecasts to 2041. Ontario Ministry of Infrastructure.

Greenwood, S. (2014). Water insecurity, climate change and governance in the Arab world. Middle East Policy, 21(2), 140-156.

Hall, J. (2015, September 19). Conservatives pledge to speed admittance of Syrian refugees. The Toronto Star. Retrieved from http://www.thestar.com/news/canada/2015/09/19/governmenteases-rules-on-syrian-refugee-claims-but-maintains-security-paramount.html

Hari, A. (2014). Temporariness, rights, and citizenship: the latest chapter in Canada's exclusionary migration and refugee history. Refuge, 30(2), 35-44.

Hartmann, B. (2010). Rethinking climate refugees and climate conflict: Rhetoric, reality and the politics of policy discourse. Journal of International Development, 22(2), 233-246.

Hiebert, D., Canada, Citizenship and Immigration Canada, \& Research and Evaluation Branch. (2012). A new residential order?: the social geography of visible minority and religious groups in Montréal, Toronto, and Vancouver in 2031. Ottawa: Citizenship and Immigration Canada.

Hiebert, D. (2015). Ethnocultural Minority Enclaves in Montreal, Toronto and Vancouver. Institute for Research on Public Policy. Retrieved from http://irpp.org/research-studies/study-no52/ 
Intergovernmental Panel on Climate Change (Eds.). (2015). Climate change 2014: synthesis report. Geneva, Switzerland: Intergovernmental Panel on Climate Change.

International Organisation for Migration (IOM). (2007). Discussion note: migration and the environment. Geneva, Switzerland: International Organization for Migration.

Johnstone, S., \& Mazo, J. (2011). Global Warming and the Arab Spring. Survival, 53(2), 11-17.

Keung, N. (2013, December 15). Asylum claims plummet - but is Canada sacrificing refugees for efficiency? The Toronto Star. Retrieved from http://www.thestar.com/news/canada/2013/12/15/asylum_claims_plummet_but_is_canada_sacrif icing_refugees_for_efficiency.html

Keung, N. (2015, July 23). Court rules denial of appeals for "safe country" refugees unconstitutional. The Toronto Star. Retrieved from http://www.thestar.com/news/immigration/2015/07/23/courtstrikes-down-ottawas-safe-country-list-for-refugees.html

Kestler-D’Amours, J., Edwards, P., MacCharles, T., \& Gallant, J. (2015, September 3). Tima Kurdi's pleading letter to allow brother to enter Canada revealed. The Toronto Star. Retrieved from http://www.thestar.com/news/world/2015/09/03/canada-rejected-request-to-take-in-family-ofdrowned-syrian-boy.html

Knowles, V. (2007). Strangers at Our Gates: Canadian Immigration and Immigration Policy, 15402006. Toronto: Dundurn.

Lamba, N. K., \& Krahn, H. (2003). Social capital and refugee resettlement: The social networks of refugees in Canada. Journal of International Migration and Integration, 4(3), 335-360.

Ligeti, E., Wieditz, I., \& Penney, J. (2006). A Scan of Climate Change Impacts on Toronto. The Clean Air Partnership. 
Logan, J., \& Murdie, R. (2016). Home in Canada? The Settlement Experiences of Tibetans in Parkdale, Toronto. Journal of International Migration and Integration, 17(1), 95-113.

Lovelock, J. (2009). The Vanishing Face of Gaia: A Final Warning. New York: Basic Books.

Makwarimba, E., Stewart, M., Simich, L., Makumbe, K., Shizha, E., \& Anderson, S. (2013).

Sudanese and Somali Refugees in Canada: Social Support Needs and Preferences. International Migration, 51(5), 106-119.

Marchiori, L., \& Schumacher, I. (2011). When nature rebels: international migration, climate change, and inequality. Journal of Population Economics, 24(2), 569-600.

Matthew, R. A. (2011). Is Climate Change a National Security Issue? Issues in Science and Technology, 27(3), 49.

McLeman, R. (2013). Developments in modelling of climate change-related migration. Climatic Change, 117(3), 599-611.

McLeman, R. (2014). Climate and human migration: Past experiences, future challenges. New York: Cambridge University Press.

Meierding, E. (2013). Climate Change and Conflict: Avoiding Small Talk about the Weather. International Studies Review, 15(2), 185-203.

Mensah, J., \& Williams, C. J. (2013). Ghanaian and Somali Immigrants in Toronto's Rental Market: A Comparative Cultural Perspective of Housing Issues and Coping Strategies. Canadian Ethnic Studies, 45(1-2), 115-141.

Mensah, J., \& Williams, C. J. (2014). Cultural Dimensions of African Immigrant Housing in Toronto: A Qualitative Insight. Housing Studies, 29(3), 438-455.

Methmann, C., \& Oels, A. (2015). From “fearing” to “empowering” climate refugees: Governing climate-induced migration in the name of resilience. Security Dialogue, 46(1), 51-68. 
Meyers, N. (2002). Environmental refugees: A growing phenomenon of the $21^{\text {st }}$ century. Philosophical Transactions of the Royal Society B357 (1420), 609-613.

Mooney, C. (2016, February 18). Scientists are floored by what's happening in the Arctic right now. The Washington Post. Retrieved from https://www.washingtonpost.com/news/energyenvironment/wp/2016/02/18/scientists-are-floored-by-whats-happening-in-the-arctic-right-now/

Murdie, R., \& Ghosh, S. (2010). Does Spatial Concentration Always Mean a Lack of Integration? Exploring Ethnic Concentration and Integration in Toronto. Journal of Ethnic and Migration Studies, 36(2), 293-311.

Murdie, R. (2010). Precarious beginnings: the housing situation of Canada's refugees. Canadian Issues, 47.

Murdie, R. A. (2003). Housing affordability and Toronto's rental market: perspectives from the housing careers of Jamaican, Polish and Somali Newcomers. Housing, Theory and Society, 20(4), 183-196.

Murdie, R. A. (2008). Pathways to Housing: The Experiences of Sponsored Refugees and Refugee Claimants in Accessing Permanent Housing in Toronto. Journal of International Migration and Integration, 9(1), 81-101.

Murray, S. (2010). Environmental migrants and Canada's refugee policy. Refuge, 27(1).

National Intelligence Council (U.S.). (2012). Global trends 2030: alternative worlds: a publication of the National Intelligence Council. December 2012.

National Snow and Ice Data Center. (2016, February 4). January hits new record low in the Arctic. Retrieved February 28, 2016, from http://nsidc.org/arcticseaicenews/2016/02/january-hits-newrecord-low-in-the-arctic/ 
New York City Panel on Climate Change. (2015). NPCC 2015 Report Executive Summary. Annals of the New York Academy of Sciences, 1336(1), 9-17.

Nicholson, C. T. M. (2014). Climate change and the politics of causal reasoning: the case of climate change and migration. The Geographical Journal, 180(2), 151-160.

OCASI (Ontario Council of Agencies Serving Immigrants). (2012). Making Ontario Home: A Study of Settlement and Integration Services for Immigrants and Refugees.

Retrieved March 3, 2016, from http://www.ocasi.org/downloads/OCASI_MOH_ENGLISH.pdf

Obokata, R., Veronis, L., \& McLeman, R. (2014). Empirical research on international environmental migration: a systematic review. Population and Environment, 36(1), 111-135.

O’Loughlin, J., Linke, A. M., \& Witmer, F. D. W. (2014). Effects of temperature and precipitation variability on the risk of violence in sub-Saharan Africa, 1980-2012. Proceedings of the National Academy of Sciences, 111(47), 16712-16717.

Omerizie, E., \& Gore, C. (2011). Temporary Measures: Canadian Refugee Policy and Environmental Migration. Refuge, 29(2), 43-53.

Ontario Ministry of Housing. (2015). Average Rents in Ontario for Apartments - 2015: Privately Initiated Apartment Structures with Three or More Units by Bedroom Types. Government of Ontario. Retrieved from http://www.mah.gov.on.ca/AssetFactory.aspx?did=13593

Oppenheimer, M. (2012). Climate change impacts: accounting for the human response. Climatic Change, 117(3), 439-449.

Pal, J. S., \& Eltahir, E. A. B. (2016). Future temperature in southwest Asia projected to exceed a threshold for human adaptability. Nature Climate Change, 6.

Pearce, F. (2011). Searching for the climate refugees. New Scientist. April, 6-7. 
Perch-Nielsen, S., B. Bättig, M., \& Imboden, D. (2008). Exploring the link between climate change and migration. Climatic Change, 91(3-4), 375-393.

Preston, V., Murdie, R., D’Addario, S., Sibanda, P., Murnaghan, A. M., Logan, J., \& Ahn, M. H. (2011). Precarious Housing and Hidden Homelessness Among Refugees, Asylum Seekers and Immigrants in the Toronto Metropolitan Area (Working Paper No. 87). Toronto: Ryerson University School of Early Childhood Education.

Preston, V., Murnaghan, A. M., Murdie, R., Logan, J., Wedlock, J., Agrawal, S., Kwak, M. J. (2010). Seeking Affordable Homeownership in the Suburbs: A Case Study of Immigrants in York Region. Canadian Issues, 40.

Qadeer, M. A., Agrawal, S. K., \& Lovell, A. (2010). Evolution of Ethnic Enclaves in the Toronto Metropolitan Area, 2001-2006. Journal of International Migration and Integration / Revue de L'integration et de La Migration Internationale, 11(3), 315-339.

Qadeer, M. A. (2009). Multicultural Planning? Plan Canada, 10-13.

Raleigh, C., \& Urdal, H. (2007). Climate change, environmental degradation and armed conflict. Political Geography, 26(6), 674-694.

Raleigh, C., Jordan, L., \& Salehyan, I. (2008). Assessing the impact of climate change on migration and conflict. In Paper commissioned by the World Bank Group for the Social Dimensions of Climate Change workshop, Washington, DC. Washington, DC: The World Bank.

Ransan-Cooper, H., Farbotko, C., McNamara, K. E., Thornton, F., \& Chevalier, E. (2015). Being(s) framed: The means and ends of framing environmental migrants. Global Environmental Change, $35,106-115$.

Rencz, A. N. (2012). Climate Change Geoscience Program: 2006-2011 program final report (No. 6879). 
Reuveny, R., \& Barbieri, K. (2014). On the effect of natural resources on interstate war. Progress in Physical Geography, 38(6), 786-806.

Reuveny, R. (2007). Climate change-induced migration and violent conflict. Political Geography, 26(6), 656-673.

Reynolds, C., \& Goffin, P. (2016, January 20). Five-day pause put on Toronto refugee arrivals. The Toronto Star. Retrieved from http://www.thestar.com/news/immigration/2016/01/20/five-daypause-put-on-toronto-refugee-arrivals.html

Rider, D. (2015, September 10). Toronto mayor, religious leaders join together to help Syrian refugees. The Toronto Star. Retrieved from http://www.thestar.com/news/gta/2015/09/10/mayorjohn-tory-wants-to-help-syrian-refugees-arrive.html

Sandford, R. W. (2012). Cold matters: the state and fate of Canada's fresh water. Victoria, BC: Rocky Mountain Books.

Stern, N. (2007). The Economics of Climate Change: The Stern Review. Cambridge University Press, Cambridge.

Teixeira, C. (2008). Barriers and outcomes in the housing searches of new immigrants and refugees: a case study of "Black" Africans in Toronto's rental market. Journal of Housing and the Built Environment, 23(4), 253-276.

Toronto Environment Office. (2008). Ahead of the Storm: Preparing Toronto for Climate Change. Toronto: City of Toronto Climate Adaptation Steering Group.

Tol, R. S., Downing, T. E., Kuik, O. J., \& Smith, J. B. (2004). Distributional aspects of climate change impacts. Global Environmental Change, 14(3), 259-272.

Tolley, Erin. \& Young, Robert. (2011). Immigrant settlement policy in Canadian municipalities. Montreal: McGill-Queen's University Press. 
United Nations. (2015, December 12). Adoption of the Paris Agreement: Draft Decision CP.21. Framework Convention on Climate Change.

UN General Assembly. (1951). Convention Relating to the Status of Refugees. United Nations Treaty Series. Vol. 189.

Veronis, L., \& McLeman, R. (2014). Environmental influences on African migration to Canada: focus group findings from Ottawa-Gatineau. Population and Environment, 36(2), 234-251.

Wallace, M. L., \& Milroy, B. M. (2004). Ethnoracial diversity and planning practices in the Greater Toronto Area: final report. Joint Centre of Excellence for Research on Immigration and Settlement, 12, 1-7.

Wang, M., \& Overland, J. E. (2012). A sea ice free summer Arctic within 30 years: An update from CMIP5 models. Geophysical Research Letters, 39(18), L18501.

Wang, X., Huang, G., \& Liu, J. (2015). Projected increases in near-surface air temperature over Ontario, Canada: a regional climate modeling approach. Climate Dynamics, 45(5-6), 1381-1393. Wang, X., Huang, G., Liu, J., Li, Z., \& Zhao, S. (2015a). Ensemble Projections of Regional Climatic Changes over Ontario, Canada. Journal of Climate, 28(18), 7327-7346.

Warner, K., Hamza, M., Oliver-Smith, A., Renaud, F., \& Julca, A. (2010). Climate change, environmental degradation and migration. Natural Hazards, 55(3), 689-715.

Warner, K., Ehrhart, C., de Sherbinin, A., Adamo, S., \& Chai-Onn, T. (2009). In search of shelter. Mapping the Effects of Climate Change on Human Migration and Displacement. Bonn: CARE. Retrieved from http://srdis.ciesin.org/documents/ClimMigr-rpt-june09.pdf

Williamson, T. B., Northern Forestry Centre (Canada), \& Sustainable Forest Management Network (Eds.). (2009). Climate change and Canada's forests: from impacts to adaptation. Edmonton: Sustainable Forest Management Network. 
Wodon, Q., Liverani, A., Joseph, G., \& Bougnoux, N. (Eds.). (2014). Climate Change and Migration: Evidence from the Middle East and North Africa. The World Bank.

Wood, P. B., McGrath, S., \& Young, J. (2011). The Emotional City: Refugee Settlement and Neoliberal Urbanism in Calgary. Journal of International Migration and Integration.

Yonetani, M. (2011). Global Estimates 2015: People Displaced by Disasters. Internal Displacement Monitoring Centre.

Zhuang, Z. C. (2013). Rethinking multicultural planning: an empirical study of ethnic retailing. Canadian Journal of Urban Research, 22(2), 90. 